\title{
Tax Reform and Incentives to Encourage Owner-Occupied Housing: Analysis of the President's Tax Reform Panel Recommendation to Convert the Mortgage Interest Deduction to a Tax Credit
}

\author{
John E. Anderson \\ Department of Economics, University of Nebraska-Lincoln \\ Jeffrey P. Clemens \\ Department of Economics, Harvard University \\ Andrew R. Hanson \\ Department of Economics, Syracuse University
}

\begin{abstract}
Public policy designed to encourage home ownership has operated primarily through the federal income tax system in the United States. With multiple incentives for homeownership, the income tax system is the main tool by which the federal government encourages families to become home-owners and accumulate wealth in the form of real estate. Recent policy debate over reform of the tax system has questioned whether a mainstay of this system, the mortgage interest deduction (MID), is the best way to accomplish the stated objective. Last year the President's Advisory Panel on Federal Tax Reform recommended converting the MID into a $15 \%$ tax credit subject to regional caps related to median house prices, touching off a vigorous public debate on the importance of the MID. The purpose of this paper is to examine economic implications of that recommendation. We model how switching from the MID to a credit would affect housing finance choices between debt and equity and show how these changes would have changed the tax benefits for various households. Furthermore, we simulate the number of mortgage originations in 2004 (the most recent year which data is available) that would have been subject to the caps in the Panel's recommendation, and we identify the specific urban housing markets that would have been most severely affected. Finally, we conclude with policy discussion of the proposed credit alternative.
\end{abstract}

This paper was prepared for presentation at Closing the Wealth Gap: A Policy Research Forum, sponsored by the Community Affairs Offices of the Federal Reserve System and CFED, September 19-21, 2006, Phoenix, Arizona. 


\section{Introduction and Background:}

Public policy designed to encourage home ownership has operated primarily through the federal income tax system in the United States. With multiple incentives for home-ownership, the income tax system is the main tool by which the federal government encourages families to become home-owners and accumulate wealth in the form of real estate. Net housing wealth as a share of total net worth has historically fluctuated between 17 and $28 \%$ with an average of $23 \%$ since 1952. Recently, this share has risen steadily from a low of $17 \%$ in the fourth quarter of 1999 to its current $25 \%$ of total net worth. Home mortgages are a key component to calculating housing wealth. From an accounting perspective, home mortgages are subtracted from home equity, making them, at least initially, yield no net benefit in terms of accumulated wealth. Taking a long-term perspective, however, mortgages can make purchasing a home feasible for consumers who cannot finance with equity. This option makes home ownership possible for a greater number of consumers and assists in the accumulation of housing wealth in the long term. The largest subsidy in the federal income tax code aimed at encouraging homeownership is based on interest paid on a home mortgage. The mortgage interest deduction (MID) allows taxpayers to deduct interest paid on a mortgage from their taxable income.

The U.S. government's Office of Management and Budget (2006) estimates that the deduction for mortgage interest will reduce income tax revenues by $\$ 79.9$ billion in fiscal year 2007. This will make it the second largest tax expenditure in the federal income tax code, behind only the exclusion of employer contributions for medical insurance premiums and medical care. The deduction allows homeowners to reduce their taxable income by the amount of interest paid on a first home as well as for interest paid on second home mortgages and home equity loans. 
The effect of these subsidies is to alter the price of owner-occupied housing for taxpayers who claim these deductions, making it more attractive to purchase a home ${ }^{1}$.

The MID's effectiveness at encouraging home ownership has been a point of contention. While subsidizing owner-occupied housing through the MID increases the housing stock, it may not be as effective in causing changes in tenure choice (from renting to owning) as alternative policies. Criticisms of the MID as an instrument for encouraging home ownership are based largely on the design of the subsidy. Because the subsidy takes the form of a deduction from taxable income, it is only available to taxpayers who itemize, and is also more valuable to households whose incomes put them in higher tax brackets. Also, since the subsidy is based on how much interest is paid on a mortgage, larger subsidies are given to those who purchase more expensive homes (subject to a mortgage maximum of $\$ 1$ million).

If the policy concern is to stimulate home ownership among low to moderate income households, alternative policies may be more effective than the MID. Our paper will examine the economic implications of one such alternative policy that was recently a prominent part of the President's Advisory Panel on Federal Tax Reform. The Panel recommended converting the MID into a $15 \%$ tax credit, subject to a cap on mortgage size tied to the median price of housing in the home's geographic location. Since the credit could be claimed by all home-owning families, not just itemizers as with the MID, the housing subsidy would be made available to many more families. The Panel argued that this change would encourage more home-ownership, and that the geographic caps would simultaneously remove the incentive for home-owning

\footnotetext{
${ }^{1}$ It should be noted, however, that the Office of Management and Budget estimates the cost of the MID as a tax expenditure using a simple estimation method based on the number of itemizing households and the size of the interest deductions. Some research suggests that behavioral responses to the elimination of the MID may make the actual cost much smaller. For example, Follain and Melamed (2001) argue that elimination of the MID would induce households to refinance their homes, substituting equity for debt. Taking this portfolio shuffling into account, they estimate that elimination of the MID would add only \$10 billion in additional revenue each year
} 
families to consume larger amounts of housing. Reducing the size of the tax incentive for these families on their inframarginal housing purchases would better target the subsidy at its goal.

This paper is the first to model how the Panel's proposal would affect housing finance choices between debt and equity and show how these changes would have changed the tax benefits for various households. The model highlights why the benefits of the MID go primarily to high income families (namely higher marginal tax rates, higher house prices, and higher likelihood of itemizing), and how far a capped credit can go towards targeting the incentive to individuals who are more likely to be on the margin between ownership and renting. We are also the first to use 2004 HMDA data on actual mortgages to simulate the number of mortgage originations that would have been subject to the caps in the Panel's recommendation, and identify the specific urban housing markets that would have been most severely affected. Our paper also offers a unique breakdown of how the proposed policy would affect homebuyers of different races, income levels, and mortgage amounts.

The remainder of the paper begins with a discussion of the previous literature on subsidizing home ownership. We then outline a model that shows how offering a mortgage interest tax credit (with the proposed caps) differs from a deduction in terms of its implications for the user cost of owner occupied housing. We continue by giving a detailed explanation of the President's Advisory Panel's recommendation for changing this subsidy, including how the location-specific caps are calculated. We estimate the number of mortgages that would have been affected by these caps (in 2004) at the MSA, state and national level, including summary statistics on the income and race of applicants for both the entire sample of mortgage originations in 2004 and the mortgage originations that were for amounts above the proposed caps. We estimate that while only $13 \%$ of mortgage originations would be affected nationwide, 
some geographic areas will be affected more significantly than others. At the state level, the percent of affected mortgage originations reaches a high of $26 \%$ in California, while at the MSA level it reaches a high of $67.5 \%$ in San Francisco. We then discuss the proposed policy changes with attention given to how they may impact housing wealth. The final section of the paper discusses come the concerns with transitioning from the current law to the Panel's recommendation and concludes.

\section{Previous Studies:}

Economists have long been concerned about the efficiency and equity effects of housing subsidies. Rosen (1985) reviews the early literature, which found that these subsidies have significant effects on both the choice between owner-occupied and rental housing and on the quantity of housing consumed. Conditional on home ownership, Rosen (1979) estimates that without tax subsidies U.S. residents would have lived in homes that were $9-17 \%$ less valuable than their current homes in 1970. The range of estimates in that study is due to differences across the income distribution. King (1981) similarly estimates that the elimination of tax subsidies for housing in the United Kingdom would reduce the quantity of housing consumed by about $13.7 \%$.

Rosen (1979) also translates these consumption distortions into efficiency loss estimates. He calculates that his estimates for the year 1970, mentioned above, translate into an average annual excess burden of about $\$ 192$ in 1980 dollars. Rosen (1985) also notes that some of the early literature expressed a concern that subsidy-induced housing consumption comes at the expense of business investment (e.g., Summers, 1980). However, he notes that prior to 1985 the econometric evidence on this issue was insufficient to establish this relationship. 
Mills (1989) provides evidence on the efficiency of the allocation of the capital stock in the United States. He uses national income data over the period 1929-1986 and computes the return to housing capital compared to all other private fixed capital. His results indicate that the real returns to capital have been smaller in housing than for non-housing fixed capital, suggesting overinvestment in housing. The President's advisory Panel (2005) report includes a comparison of the effective tax rates on different types of investment, as calculated by the Treasury Department. Their estimates report that the marginal effective tax rate for owner occupied housing is $0 \%$, while the rate is $17 \%$ for non-corporate business, $26 \%$ for corporate business, $22 \%$ for the business sector as a whole, and $14 \%$ economy-wide. Such differences in effective tax rates are ultimately bound to cause distorted allocation of capital.

Rosen (1985) also discusses two significant early studies on the choice between owneroccupied and rental housing. Rosen and Rosen (1981) estimate that tax subsidies for owneroccupied housing raised the home-ownership rate by about $4 \%$ in 1974 . Hendershott and Shilling (1982) make slightly higher estimates (5-6.5\%) depending on the assumed average marginal income tax rate.

On the equity front, both Rosen (1979) and King (1981) extend their analyses to assess the distributional implications of eliminating housing tax subsidies. Both studies find that the elimination of these subsidies would tend to reduce income inequality relative to the status quo. Rosen (1979) shows that this result would hold in the United States (although to a lesser degree) even if total tax revenues are kept constant through a proportional tax cut.

More recently, Follain and Ling (1991) analyzed the effects of the Tax Reform Act of 1986 (TRA86) on both renters and home owners. TRA86 reduced the overall size of the federal 
housing subsidy by more than $30 \%$. It did that by reducing subsidies for both renters and owners. For owner-occupants the value of the MID fell as marginal tax rates were reduced.

Their most surprising result was that the distribution of the housing subsidy was just as skewed in favor of high-income households after TRA86 as it was before. According to their estimates, the top $12 \%$ of the income distribution receives about $54 \%$ of the housing subsidy. Their result was surprising since TRA86 reduced marginal income tax rates, the most important determinant of the size of the housing subsidy. In fact, the reductions in marginal income tax rates were largest for high-income taxpayers, leading to the expectation that the subsidy would be less progressively distributed after the tax reform. They found that the distribution of housing subsidy benefits was not improved due to the fact that other elements of TRA86 reduced the value of the MID for low and moderate income households. These elements included an increase in the standard deduction and a reduction of the number and size of non-housing deductions. Follain and Ling show that the MID was made essentially worthless for many households with incomes below $\$ 42,500$.

The advantages of the MID also apply unevenly across regions of the country due to variations in the rate of itemization and housing prices. The result is that the incentive effects of the MID are not uniform, but vary in systematic ways across regions and metropolitan areas. Using 1995 IRS tax data, Brady, Cronin and Houser (2003) found, for example, that just $21 \%$ of taxpayers itemize in the West South Central region of the United States, while 38\% itemize in the New England and Mid-Atlantic regions. For those taxpayers that do itemize, the average size MID varies from $\$ 5,700$ in the West North Central division to $\$ 10,000$ in the Pacific division. The average tax savings due to the MID ranged from $\$ 1,100$ in the East South Central division to $\$ 2,100$ in the Pacific division. $\mathrm{BCH}$ also investigated the regional causes of MID variation, 
finding that income variation accounts for part, but not nearly all, of the variation. They found that the percentage of tax returns with itemized deductions for all census regions rose from $3.1 \%$ for filers with income between $\$ 0$ and $\$ 14,999$ to $91.7 \%$ for filers with income in excess of $\$ 200,000$. Both individual characteristics (e.g. age, tax filing status, and number of dependents) and regional characteristics (e.g. housing prices and state/local taxes) account for a substantial share of the variation in MID usage and size. Regional variation in house prices and state/local taxes account for $61 \%$ of the regional variation in the probability of itemizing, and $67 \%$ of the variation in the amount of MID interest deducted.

Poterba (1992) also analyzed the distribution of the MID before and after TRA86, confirming this pattern. He found, for example, that the percentage of taxpayers with income of $\$ 30,000$ or less claiming the MID fell from $27.1 \%$ to $20.0 \%$. At the high end of the income distribution, the percentage of taxpayers claiming the deduction rose. For example, among taxpayers with income between $\$ 150,000$ and $\$ 250,000$ the percentage of taxpayers claiming the deduction rose from $69.8 \%$ to $73.7 \%$.

Anderson and Roy (2001) examined the distributional impact of elimination of housing tax preferences. In particular, they simulated the effect of eliminating both the mortgage interest and property tax deductions. Their simulations show that elimination of these housing tax preferences would increase the progressivity of the income tax significantly, as measured by the change in the Suits index, with a bootstrapped confidence interval.

\section{Modeling Housing Tax Subsidies:}

In this section we present a simple model of the user cost of home ownership that highlights the factors affecting the size of the housing tax subsidy provided by the U.S. tax 
system. We begin with a model of the user cost of ownership that assumes the real economic profit from homeownership is fully taxed. Using that model as a benchmark, we then introduce tax incentives found in the U.S. tax system and consider the effects for both itemizers and nonitemizers. The model reveals how the size of the housing tax subsidy varies with the home price, mortgage interest rate, share of the house price that is debt financed, marginal income tax rate, and the property tax rate. With knowledge of the determinants of the subsidy size, we then derive implications for household decisions regarding tenure choice (rent vs. own) and the quantity of housing to consume. We then modify the model to consider the potential effects of switching from a MID to a capped credit.

The benchmark case is that of fully taxing the real economic return to homeownership. ${ }^{2}$ Following Poterba (1992) and Glaeser and Shapiro (2002), the net-of-tax income (or economic profit) from owning a home with price $P_{H}$ with imputed rental value of $R$ for a homeowner with a marginal income tax rate of $\tau$ is:

$$
(1-\tau)\left[R-\left\{i+\tau_{\mathrm{p}}+m-\pi\right\} P_{H}\right]
$$

where $i$ is the interest rate, $\tau_{\mathrm{p}}$ is the property tax rate, $m$ is the maintenance and depreciation cost rate, and $\pi$ is the inflation rate. The term in curled braces captures the homeowner's forgone equity cost minus any capital gain. The equity cost includes the foregone interest on the housing asset plus the property taxes and maintenance and depreciation costs. The nominal capital gain to the owner is the rate of inflation applied to the price of the house.

In a competitive equilibrium the net economic income from homeownership is driven to zero. Setting the above expression equal to zero and solving for $R$ results in the equilibrium condition of the imputed rent expression:

\footnotetext{
${ }^{2}$ We ignore capital gains taxation in this treatment.
} 


$$
R=\left[i+\tau_{\mathrm{p}}+m-\pi\right] P_{H} .
$$

This is the competitive equilibrium rent that would occur if the income tax system fully taxed the net income from housing as it taxes the interest earned on other investments. It represents the cost of housing to the homeowner.

\section{Housing Subsidy for Itemizers}

Now, consider the effects of the U.S. income tax system, which deviates from this standard. Most importantly, the U.S. income tax system does not tax the implicit rental income from housing, while it does permit deductions for mortgage interest and local property taxes. For an itemizer, the user cost is reduced due to deductibility of mortgage interest and property taxes. The MID is limited to mortgages of $\$ 1$ million or less for a married couple where the proceeds are used to buy, build, or improve the home. It is limited to mortgages of $\$ 100,000$ or less where the proceeds are used for purposes other than to buy, build, or improve the home (e.g. home equity line of credit to pay off consumer debt, buy a car, or pay tuition). These limits are cut in half for single filers.

The foregone interest on the equity in the housing asset is the after-tax interest rate $(1-\tau) i$. The interest rate paid on the debt portion of the housing asset is the same after-tax interest rate due to the MID. Hence the rental price of housing for an itemizer $R_{I}$ is:

$$
\begin{aligned}
R_{I} & =\left[(1-\tau)\left(i+\tau_{\mathrm{p}}\right)+m-\pi\right] P_{H} \\
& =R-\tau\left(i+\tau_{\mathrm{p}}\right) P_{H} .
\end{aligned}
$$

In these ways the tax system reduces the cost of housing. The cost reduction $\tau\left(i+\tau_{\mathrm{p}}\right) P_{H}$ depends upon the taxpayer's marginal tax rate, the interest rate, the property tax rate, and the house price. Thus, the housing tax subsidy for itemizers varies directly with marginal income tax rate, the interest rate, the property tax rate, and the price of the house. The housing subsidy is more 
valuable for high-income home-owing taxpayers in regions of the country where home prices are high and property tax rates are also high.

\section{Housing Subsidy for Non-Itemizers}

Non-itemizers face a different situation based on the fact that two different net-of-tax interest rates apply to the equity and debt portions of their housing asset. On the debt portion, the after-tax cost of borrowing is the full interest rate $i$ due to the absence of the MID. The

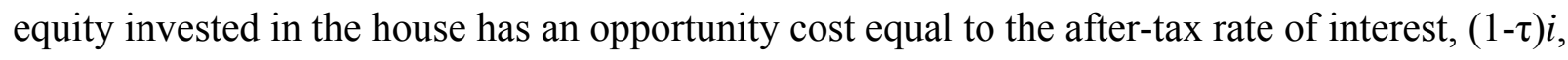
however. It is therefore necessary to separate the interest rate component of the user cost into two parts to show the after-tax price difference between debt and equity financing. If the share of the house price financed with debt is represented by the parameter $\theta$, then the rental price of housing for the non-itemizer $\left(R_{N I}\right)$ is:

$$
\begin{aligned}
R_{N I} & =\left[(1-\theta)(1-\tau) i+\theta i+\tau_{\mathrm{p}}+m-\pi\right] P_{H} \\
& =R-\tau(1-\theta) i P_{H} .
\end{aligned}
$$

The income tax system reduces the relative price of owning a home for the non-itemizer by the amount $\tau(1-\theta) i P_{H}$. Hence, for non-itemizers, the cost of homeownership is only subsidized on the portion of the home that is paid in equity $(1-\theta)$. This provides an incentive for such taxpayers to pay down their mortgages quickly assuming that they have chosen to purchase a home in the first place.

For a given equity ratio, the higher the marginal tax rate or the equity share, the greater the subsidy, other things being equal. On both counts, recent developments in tax policy and mortgage markets reduce the housing subsidy for non-itemizers. Reductions in marginal tax rates in 2001 and 2003, along with new mortgage products that reduce the equity share (by lowering the down payment and raising the loan-to-value ratio), would both have this effect. 


\section{Alternative Housing Subsidy with a Mortgage Credit}

Now, suppose that instead of the MID there is a mortgage interest credit subject to a cap based on area home prices as was recently recommended by the President's Tax Reform Panel (discussed in detail in the next section). The credit is based on the amount of interest paid on the house mortgage debt, for houses whose price does not exceed the cap $\bar{P}_{H}$; otherwise the credit is capped at the amount determined by the maximum house price. We can write the credit as $C=$ $c i \theta P_{H}$, where $c$ is the credit rate and $\theta$ is the share of the home price that is debt-financed. The rental price of housing for a non-itemizer receiving such a credit is:

$$
\begin{aligned}
R_{C} & =\left[(1-\theta)(1-\tau) i+\theta i s+(1-c) \theta i(1-s)+\tau_{\mathrm{p}}+m-\pi\right] P_{H} \\
& =R-\{\tau(1-\theta)+c \theta(1-s)\} i P_{H},
\end{aligned}
$$

where $s$ is the share of the mortgage that is above the proposed cap, which depends on the median regional home price.

Compared to the non-itemizing case, the mortgage interest credit reduces the cost of homeownership by an additional amount that depends on the credit rate $c$ and the interest paid on the amount of a mortgage below the cap, $\theta(1-s) i P_{H}$. Unlike the non-itemizer under the MID regime, in this case a homeowner with no equity receives a housing subsidy equal to the second term in curled braces in the expression above. In this way the credit has an incentive effect for first-time homebuyers with little or no equity.

Furthermore, notice that under the mortgage credit regime, the non-itemizing homeowner confronts a debt-equity tradeoff in the housing subsidy. As the debt parameter $\theta$ increases the first term of the subsidy shrinks while the second term grows. On balance, the size of the subsidy depends on the relative sizes of the marginal tax and credit rates. Homeowners whose marginal tax rate is above the marginal credit rate will obtain a larger subsidy by decreasing their 
home debt and financing with equity, other things being equal. On the other hand, homeowners whose marginal tax rate is below the marginal credit rate obtain a larger subsidy by putting as little down as possible and debt-financing as much of the home price as possible.

\section{Incentive Effects}

Both the MID and the credit mechanism provide incentives for households to consume housing, although the housing subsidy magnitudes and marginal incentives differ. The MID has incentive effects for itemizers only. The subsidy provided to itemizers is proportional to the interest rate, marginal income tax rate, the price of the house, and the fraction of the house that is financed with debt. Non-itemizers receive no specific benefit from the MID, although they do receive other subsidies from the tax system as discussed above (e.g. non-taxation of the implicit return on equity). The subsidy provided by the credit mechanism applies to itemizers and nonitemizers alike, and is proportional to the interest rate, the credit rate, and the price of the house, and the fraction of the house that is financed with debt. But, the cap affects the size of the credit, depending on the relative sizes of the marginal income tax and credit rates and the share of the mortgage exceeding the cap.

As a consequence of the cap feature of the credit mechanism the marginal incentives provided differ. The MID, provides an incentive for itemizers to purchase a home and consume larger quantities of housing. Furthermore, since the MID is effectively unlimited (interest on mortgages up to $\$ 1$ million is deductible for a married couple) it continues to subsidize the purchase of additional housing, once the tenure choice decision has been made. The credit mechanism, on the other hand, provides an incentive for ownership for all taxpayers (unambiguously) and limits the incentive to consume more housing. Once the cap is reached, the marginal incentive is zero. Thus, the MID subsidizes both marginal and infra-marginal 
purchases of housing, but the credit subject to a cap stops subsidizing marginal housing purchases once the cap is reached.

Using data from the Federal Reserve Board's Survey of Consumer Finances, Table 1 illustrates the tax savings that are realized by families across the income distribution as a result of the MID. It also contrasts these savings with those that would be realized under a $15 \%$ credit. As discussed above, tax savings are calculated as $\tau i \theta P_{H}$ in the case of the MID and as $c i \theta P_{H}$ in the case of the credit, with the limitation that the MID cannot be claimed on mortgages in excess of $\$ 1$ million, and that the credit cannot be claimed on mortgages in excess of the regional caps.

Among those who benefit from the MID (i.e., itemizers with mortgage debt), tax savings for those at the median of the top $10 \%$ of the income distribution $(\$ 4,151)$ will be about 16.5 times the tax savings for those at the median of the bottom $20 \%(\$ 252)$. This is driven by both the higher tax rates faced and the larger mortgages held by those at the high end of the income distribution. Switching from the MID to the a $15 \%$ credit undoes the effect of differential tax rates, reducing the benefit for those at the median of the top $10 \%$ of the distribution to $\$ 1,887$, and raising the benefit for those at the median of the bottom $20 \%$ to $\$ 377$. Switching to the credit mechanism also levels the benefits received by itemizers and non-itemizers. Also of note, the Survey of Consumer Finances reports that only $15.9 \%$ of those in the bottom $20 \%$ of the income distribution held mortgage debt, while $76.2 \%$ of those in the top $20 \%$ help such debt.

\section{Mortgage Credit Simulations:}

Recommendations of the President's Advisory Panel

The Panel recommended replacing deductibility of mortgage interest paid with a new "Home Credit" to be claimed against tax liability. The proposed credit would be for $15 \%$ of the 
interest paid on a mortgage in any given tax year and would not be allowed for interest paid on mortgages of second homes or home-equity loans (as is allowed under current law). In addition to switching from a deduction to a credit, the size of the mortgage that a credit can be claimed against is capped according to regional home values (currently the MID is subject to a national limit of $\$ 1$ million).

The regional mortgage limits were set by the Panel using a formula that is based on the Federal Housing Administration's (FHA) limit for insuring mortgages. The Federal Housing Administration insures loans from private lenders given to qualified high risk borrowers used for purchasing a home. The maximum amount of these loans varies by county. The maximum loan amount allowed in each county depends on the median house price of all other counties within the metropolitan statistical area (MSA). The county in the MSA with the highest median house price sets the FHA loan maximum for all other counties within the MSA. These limits also depend on the conforming loan limit set by Fannie Mae and Freddie Mac. The conforming loan limit is the maximum loan that Fannie and Freddie will take on and is based on an index of house prices that is updated annually using a survey of realtors and mortgage providers. The FHA uses the following guidelines for setting the maximum loan they will insure in an MSA:

- If $95 \%$ of the median house price is below $48 \%$ of the conforming loan limit, then the FHA uses $48 \%$ of the conforming loan limit set by Fannie Mae and Freddie Mac, currently $\$ 172,632$.

- If $95 \%$ of the median house price is above $87 \%$ of the conforming loan limit, then the FHA uses $87 \%$ of the conforming loan limit set by Fannie and Freddie, currently $\$ 312,895$.

- If $95 \%$ of the median house price is between these limits, then the FHA uses $95 \%$ of the median house price as the loan limit in that MSA.

The Panel proposed using $131.5 \%$ of the FHA loan limit in each county to approximate the average home price in each county. This amount is the mortgage cap, a taxpayer could only 
claim a credit for interest paid on a loan having a value below that level. The caps we have calculated in this paper are based on 2004 FHA loan limits and range from a low of $\$ 210,758$ to a high of $\$ 381,999$. The FHA floor takes affect in calculating the caps for 2,598 counties. The FHA ceiling takes affect in calculating the caps for 90 counties mostly in large metropolitan or costal areas including 25 of the 58 counties in California and 12 of the 21 counties in New Jersey.

\section{Estimates of Mortgages Affected by Proposed Caps}

In order to estimate the number of mortgage originations that would have been affected by the Panel's proposed caps we used a data source that has individual mortgage amounts and geographic location identifiers. This data originated with the Home Mortgage Disclosure Act (HMDA), which was enacted by the U.S. Congress in 1975. HMDA was implemented by the Federal Reserve Board in its Regulation C, which requires lending institutions (banks, savings associations, credit unions, and other mortgage lending institutions) to report public loan data. In 2005, for example, the HMDA data reports on approximately 33.6 million loan records for calendar year 2004, reported by 8,853 financial institutions. The HMDA data include both mortgage amounts and an indicator for the county of residence. We use this data for 2004, merged with a listing of the FHA limits by county for our analysis.

The HMDA data includes not only mortgage originations, but also mortgage applications. We use only the observations where a mortgage was originated for the purchase of a home which eliminates mortgage applications for home improvement or refinancing an existing mortgage. Although the Panel recommended that the credit be allowed for mortgages used for home 
improvement and refinancing, they did not recommend specific caps for these loans. Therefore, we do not include those in our analysis.

After matching originations in the HMDA data with the county-specific proposed caps we were able to determine which observations would have lost tax-preferred status on some portion of the mortgage. We estimate that nationally about 13 percent of mortgage originations in 2004 would have been partially affected by a loss of tax preference. Of the total 6.29 million mortgage originations 832,925 were for amounts above the proposed caps.

Table 2 reports the number of originations subject to the proposed caps for each state and also reports the percentage of originations that were above the proposed caps. California has the highest percentage of mortgage originations that would be affected by the proposed caps--almost $26 \%$. North Dakota has the lowest percentage, with less than $5 \%$ of mortgage originations being affected. At the state level, the geographic pattern appears to be that costal states have a larger percentage of mortgage originations above the cap than states in the middle of the country. States with small percentages of mortgage originations subject to the cap are overwhelmingly in the Midwest and Southeast.

The HMDA data also makes it possible to sort mortgage originations at the MSA level. Since the proposed caps are related to housing prices in a given area, but have a national ceiling built in, areas with higher home prices should have a disproportionate percentage of their residents affected. Following Census rankings we check to see how the proposed caps would affect mortgage originations in both the 25 largest MSAs and the 25 fastest growing MSAs (in terms of percentage change in population from 1990 to 2000). In addition, we use rankings from the National Association of Realtors to examine how the proposed caps affect MSAs with the highest housing prices and the fastest growing housing prices. 
Table 3 reveals that the fastest growing MSAs are largely in Southeastern and Southwestern states. The pattern of MSAs affected by the caps differs little from the pattern in the state-level data. These MSAs have between 5 and $25 \%$ of mortgages above the caps. Some fast-growing MSAs have relatively few mortgages above the caps. For example, McAllenEdinburg-Mission, Texas has just $4.91 \%$ of originations above the cap. Similarly, Laredo, Texas, Yuma, Arizona, and Denver-Boulder-Greely, Colorado all have low percentages of originations above the caps. At the high end, MSAs with large fractions of originations above the caps include three metro areas in Florida, Naples, Orlando, and West Palm Beach-Boca Raton, Phoeniz-Mesa, Arizona, and Wilmington, North Carolina. It is notable, however that the fraction of originations above the caps is much different for some of these cities than for their corresponding states. For instance, the State of North Carolina has only $14 \%$ of mortgages above the cap, but Wilmington has $24 \%$ above the cap. Also note that Naples, Florida has $27 \%$ above the gap, while the State of Florida has only $16 \%$ above the cap. Clearly, the distribution of mortgages above the cap within a state can be quite variable across MSAs.

Table 4 presents the share of mortgages above the cap for the 25 largest MSAs, measured by population in the 2000 census. This table provides further evidence that the impact of the proposed caps can be highly variable. The most glaring example in the table is the San Francisco, California, MSA where over $67 \%$ of mortgage originations exceed the proposed caps, while the Los Angles MSA and the State of California as a whole have 25 and $26 \%$ of originations exceeding the caps. At the other extreme, there are cities such as Detroit, Michigan (4\%) and Miami, Florida (7.5\%) with smaller fractions of mortgage originations exceeding the caps than their states (Michigan has $8 \%$ overall, and Florida has $16 \%$ ). 
Because of the implicit national ceiling on the proposed caps, MSAs with relatively more expensive homes will have a disproportionate percentage of mortgage originations subject to the cap. To examine this issue further at the MSA level, we use rankings from the National Association of Realtors for areas with the highest median home price in 2004 and the largest percentage change in home prices from 2003 to 2004. Table 5 reports how the caps affect the MSAs with the highest median sales prices. Table 6 does the same for the MSAs with the fastest rising home prices, as measured by the change in median sales price from 2003 to 2004 .

As we would expect, MSAs with high home prices also tend to have a relatively high percentage of mortgage originations above the caps. Table 5 illustrates that for most of the top 25 highest price MSAs the percentage of originations above the cap exceeds the national average of 13\%. Four California MSAs top the high price list: San Jose-Sunnyvale-Santa Clara, San Francisco, Anaheim-Santa Ana, and San Diego-Carlsbad-San Marcos. Those MSAs have from 33 to $68 \%$ of mortgage originations exceeding the caps. Other high-price MSAs on the list are primarily in the Northeast (New York-New Jersey, Massachusetts, etc.) and Mid-Atlantic (DC, Virginia, Maryland, etc.).

Among the MSAs with the fastest rate of price increase two Nevada communities at the top of the list: Las Vegas-Paradise and Reno-Sparks. It is notable, that despite the fast rate of increase in house prices in those communities, the share of mortgage originations is only slightly above the U.S. mean. Table 6 reveals that MSAs with fast rates of house price increase do not necessarily have large proportions of mortgage originations above the proposed caps. Taken together, Tables 5 and 6 indicate that the impacts of mortgage credit caps would be felt more in high price MSAs than in MSAs with fast growing prices. 


\section{Description of Mortgages above the Proposed Caps}

The state and MSA share of mortgage originations affected by the cap offer an important look into how many taxpayers would be affected by the proposed changes to the MID. In this section we take a closer look at the size of these mortgages as well as the income and racial characteristics of those who hold them. To get a better idea of how much of the mortgage would have been over the cap for these taxpayers, Table 7 shows the average difference between the mortgage size and the cap for the mortgages above the cap in each state. Again, the pattern emerges that residents of states on the coasts would be most affected. Not only do more of these residents have mortgages affected by the proposed caps, but they would also have more mortgage dollars lose tax-preferred status. Of the ten states with the highest average amount of mortgage over the cap, 8 (CT, NY, RI, CA, MA, NJ, HI, and FL) are costal. Of the ten states with the lowest average amount of mortgage over the cap only two of them are costal (AK and LA).

The HMDA dataset also tells us the income and racial make up of those originating a mortgage in 2004 . We present a summary of the income (the applications total) and racial make up (for the primary applicant only) for all the originations (Table 8) and for comparison sake a summary of these for the applicants that have a mortgage above the proposed caps (Table 9). Not surprisingly, both the average and median income in each state is higher for the applicants who originated a mortgage above the caps. Importantly, Table 8 points to the fact that the caps would have relatively little effect on low-income individuals, who tend to be closest to the margin between ownership and renting.

On the down side, however, since the value of the proposed credit would not depend on marginal income tax rates, those with higher incomes who have mortgages above the cap stand 
to experience relatively large effective tax increases. Notably, there is overlap between residents of states with large income differences between those over the cap and all others, a high percentage of mortgages over the cap, and those with mortgages that exceed the cap by the largest amount. States having residents that overlap in these areas will face the largest effective tax increases.

In most states, the proportion of those affected by the caps who are Black is smaller than the proportion of residents who are Black, although the magnitude of this difference varies substantially. Only three states have a larger percentage of black residents who would be affected by the cap than Black residents who originate a mortgage (SD, VT, and WY) and in no case is the difference larger than .05 percentage points. This leads us to the conclusion that Black home ownership would be less affected by the proposed caps than other races, which may be important if minority home ownership is a goal of policy. A different story emerges for Asians, however, who in many cases make up a larger percentage of those affected by the caps than they do of all mortgage originations.

\section{Summary and Conclusions:}

Our estimations for mortgage originations in 2004 indicates that nationally about $13 \%$ of mortgage originations would have been partially affected by a loss of tax preference with the President's Advisory Panel recommendation for a capped credit in place of the MID. Of the total 6.29 million mortgage originations 832, 925 exceeded the proposed caps. Additionally, the number of originations subject to the proposed caps varies widely across the country. California has the highest percentage of mortgage originations that would be affected by the proposed caps-almost $26 \%$. North Dakota has the lowest percentage, with less than $5 \%$ of mortgage originations being affected. States with high percentages of mortgage originations above the 
caps tend to be costal states, while states with low percentages of mortgage originations subject to the caps tend to be in the Midwest and Southeast. Low income and black individuals are also relatively unlikely to be affected by the caps.

\section{Policy Considerations}

If policy makers are to consider eliminating the MID or replacing it with a capped credit there are a multitude of questions that should be addressed. We discuss a few of the most important of these questions here.

Should housing be subsidized by the federal government?

There appears to be a general consensus that housing should be subsidized in some way due to its positive externalities. That view is implicit in the President's charge to the Tax Reform Panel, which specified that whatever they proposed —it should retain an incentive for homeownership. This charge apparently embodies a political view that a housing subsidy is essential.

Glaeser and Shapiro (2002) summarize evidence supporting several common arguments in favor of subsidizing homeownership, most of which are dependent on the deduction's ability to encourage home ownership over renting. They note that homeownership is strongly correlated with political activism and may increase home maintenance and gardening, and that increases in local homeownership results tend to lead to increases in local house prices. Glaeser and Shapiro conclude that "the overall body of research seems to confirm positive externalities from homeownership." 
Should the subsidy be provided as a MID or a credit?

On the second question regarding the form of the subsidy, there is little direct evidence in the economics literature. What evidence exists suggests that the MID may not be an effective form of housing subsidy. While concluding that there are positive externalities from homeownership, Glaeser and Shapiro go on to note that the MID is not a particularly effective tool for subsidizing ownership. They argue that this should not be surprising for two important reasons. First, the distribution of the housing stock between single-family units (which tend to be owned) and multi-family units (which people tend to rent) is relatively fixed in the short run. Second, the MID does not effectively target families on the margin between ownership and renting since itemized deductions are more commonly claimed by, and more beneficial to, those with high incomes who are more likely to be homeowners whether or not they are subsidized.

Follain and Ling (1991) have also argued that the MID is an ineffective and expensive tool for helping low and moderate income households to become first-time homeowners. It is ineffective because most low and moderate income households do not have sufficient nonhousing deductions to take full advantage of the MID. It is expensive because its primary beneficiaries are high-income households, particularly those having recently purchased their homes. On this note, the President's Advisory Panel reports Joint Committee on Taxation (JCT) estimates that indicate over $70 \%$ of tax filers did not receive any benefit from the MID in 2002. Furthermore, their report indicates that more than 55\% of the estimated MID tax expenditure went to the $12 \%$ of taxpayers with cash incomes in excess of $\$ 100,000$ in 2004 .

Our analysis indicates that the prospect of switching from the current MID to a refundable $15 \%$ credit offers potential social benefits at little social cost (although the switch may impose fairly significant tax increases on some high income individuals). Such a credit 
would both make the subsidy available to non-itemizers and increase the size of the subsidy for those who are either paying income taxes at the $10 \%$ rate or not at all. It could thus shift the subsidy away from those who are not on the margin between ownership and renting and towards those who are. This shift makes the proposed credit a more apt tool than the deduction for generating the benefits discussed above.

Green and Vandell (1999) have examined the possibility of a revenue-neutral switch from the MID to a housing credit. Their proposed credit was a fixed dollar amount, unrelated to mortgage interest. Nonetheless, their simulations are instructive. They estimated that conversion of the deductions for mortgage interest and property taxes into a housing credit could increase aggregate homeownership rates by 3 to $5 \%$. Furthermore, they estimated that the increase in homeownership would be higher in low-income neighborhoods.

If the policy objective is to increase homeownership, tax policy should be designed to affect the price of owner-occupied housing for the non-owner contemplating ownership. This requires a marginal incentive. For current owner-occupants, however, no further incentive is needed. Moreover, no incentive should be provided for current owners to increase the amount of housing they consume. Hence, infra-marginal incentives are not needed or desired.

\section{Should the subsidy be limited?}

This question raises two issues to consider. Should the overall level of housing subsidy be limited? If so, should the limit be absolute or relative to regional home prices? In order to gain the maximum effect in inducing home ownership, rather than simply providing a general subsidy for increased housing consumption, it is essential that the subsidy be limited or capped in some way. For this reason, the Panel's proposed credit subject to caps is sound. The current 
MID is limited, but the mortgage limits are so large that they are not binding for most homeowners.

Furthermore, if some form of limit or cap is desired, then the Panel's proposal to cap the mortgage credit based on regional median home prices provides a similar level of subsidy across the country. While violating horizontal equity in an absolute sense, it accomplishes horizontal equity in a relative sense. It only accomplishes this roughly, however, as our estimates indicate very different degrees at which the caps are binding constraints across the country. This is appropriate in order to convert the policy from a general housing subsidy to an ownership inducement.

\section{What about policy transition?}

Transition is an important issue to consider in the context of policy change. The essential issue is that for existing homes whose owners take advantage of the MID, the value of the tax subsidy is capitalized into the value of the home. If the subsidy were suddenly reduced, the usercost of housing would increase, causing a downward adjustment of house prices in the short run. Over the medium run to long run, owners whose subsidy is reduced would be expected to adjust by consuming less housing. That would cause prices and quantities to fall farther in the market segment for large homes. On the other hand, former renters who were not able to take advantage of the MID would have new access to the mortgage credit that reduces the price of housing. Thus demand for owner-occupied housing in their segment of the market would be greater, causing prices and quantities to rise. Ultimately, there would be a reallocation of resources in housing markets that would take place over time.

The President's Advisory Panel recommended a five-year phase-in of the credit cap for pre-existing mortgages. They suggested that the MID mortgage limit be gradually reduced from 
the present $\$ 1$ million to $\$ 500,000$ over three years $(\$ 900,000$ in year one, $\$ 700,000$ in year two, and $\$ 500,000$ in year three). Then, in year four the deduction would be subject to a regional limit on the mortgage principle. Finally, in year five, the MID would be converted to a $15 \%$ home credit subject to the regional limit.

As with any policy regime switch, there is a trade-off between the efficiency gain from an abrupt transition and the equity gain from a slow transition. While not having a transition maximizes the potential efficiency gains, it is unfair to taxpayers who made decisions in the past based on the assumption that the policy would remain in effect into the indefinite future. A long gradual transition increases the fairness of the policy change, but reduces the potential efficiency gains from the policy switch. Ultimately, the political system must balance the efficiency and equity aspects of a policy regime switch. 
Table 1: Estimated Tax Savings from the MID and the Proposed Credit Alternative

\begin{tabular}{lcccc}
\hline & \multicolumn{2}{c}{ For Itemizers } & \multicolumn{2}{c}{ For Non-Itemizers } \\
\cline { 2 - 5 } $\begin{array}{c}\text { Percentile of } \\
\text { Income }\end{array}$ & MID & $15 \%$ Credit & MID & $15 \%$ Credit \\
\hline Less than 20 & $\$ 252$ & $\$ 377$ & $\$ 0$ & $\$ 377$ \\
$20-39.9$ & $\$ 544$ & $\$ 544$ & $\$ 0$ & $\$ 544$ \\
$40-59.9$ & $\$ 796$ & $\$ 796$ & $\$ 0$ & $\$ 796$ \\
$60-79.9$ & $\$ 1,649$ & $\$ 989$ & $\$ 0$ & $\$ 989$ \\
$80-89.9$ & $\$ 2,261$ & $\$ 1,357$ & $\$ 0$ & $\$ 1,357$ \\
$90-99.9$ & $\$ 4,151$ & $\$ 1,887$ & $\$ 0$ & $\$ 1,887$
\end{tabular}

Note: The assumed tax rates are those for filers who are married and filing jointly at the median income level for each income group. The assumed levels of debt are the median levels of primary-residence mortgage debt for the subset of families within each income group that has this type of debt.

Source: Authors' calculations using data from the Federal Reserve Board and the Internal Revenue Service. 
Table 2: State Level Mortgages Above Cap

\begin{tabular}{|c|c|c|c|}
\hline State & Total Originations & Originations Above Cap & Percent of Originations Above Cap \\
\hline $\mathrm{AL}$ & 76,095 & 8,429 & 11.08 \\
\hline AK & 13,884 & 1,245 & 8.97 \\
\hline $\mathrm{AZ}$ & 228,371 & 37,999 & 16.64 \\
\hline AR & 42,167 & 3,088 & 7.32 \\
\hline CA & 868,263 & 225,139 & 25.93 \\
\hline $\mathrm{CO}$ & 145,735 & 12,211 & 8.38 \\
\hline $\mathrm{CT}$ & 71,511 & 9,816 & 13.73 \\
\hline $\mathrm{DE}$ & 20,105 & 3,402 & 16.92 \\
\hline DC & 13,926 & 2,954 & 21.21 \\
\hline FL & 518,416 & 83,438 & 16.09 \\
\hline GA & 217,009 & 18,160 & 8.37 \\
\hline $\mathrm{HI}$ & 25,880 & 6,215 & 24.01 \\
\hline ID & 38,703 & 3,475 & 8.98 \\
\hline $\mathrm{IL}$ & 272,187 & 29,072 & 10.68 \\
\hline IN & 117,008 & 8,353 & 7.14 \\
\hline IA & 47,174 & 3,404 & 7.22 \\
\hline $\mathrm{KS}$ & 46,700 & 3,101 & 6.64 \\
\hline KY & 63,252 & 4,263 & 6.74 \\
\hline LA & 62,194 & 5,654 & 9.09 \\
\hline $\mathrm{ME}$ & 22,459 & 2,222 & 9.89 \\
\hline MD & 150,099 & 17,082 & 11.38 \\
\hline MA & 127,846 & 18,985 & 14.85 \\
\hline MI & 185,063 & 15,212 & 8.22 \\
\hline $\mathrm{MN}$ & 112,558 & 11,274 & 10.02 \\
\hline MS & 37,418 & 2,283 & 6.10 \\
\hline MO & 116,435 & 6,292 & 5.40 \\
\hline MT & 15,277 & 1,747 & 11.44 \\
\hline $\mathrm{NE}$ & 27,028 & 2,033 & 7.52 \\
\hline NV & 111,664 & 16,306 & 14.60 \\
\hline NH & 26,811 & 2,475 & 9.23 \\
\hline NJ & 169,446 & 22,452 & 13.25 \\
\hline NM & 37,268 & 3,968 & 10.65 \\
\hline NY & 233,461 & 41,914 & 17.95 \\
\hline $\mathrm{NC}$ & 179,953 & 25,945 & 14.42 \\
\hline ND & 9,435 & 415 & 4.40 \\
\hline $\mathrm{OH}$ & 206,701 & 15,387 & 7.44 \\
\hline OK & 56,829 & 3,096 & 5.45 \\
\hline OR & 89,074 & 10,709 & 12.02 \\
\hline PA & 195,297 & 18,140 & 9.29 \\
\hline RI & 20,345 & 1,230 & 6.05 \\
\hline $\mathrm{SC}$ & 90,982 & 11,856 & 13.03 \\
\hline SD & 12,348 & 844 & 6.84 \\
\hline $\mathrm{TN}$ & 119,060 & 8,963 & 7.53 \\
\hline TX & 465,041 & 40,687 & 8.75 \\
\hline UT & 65,514 & 4,638 & 7.08 \\
\hline VT & 9,592 & 1,380 & 14.39 \\
\hline VA & 212,454 & 26,992 & 12.70 \\
\hline WA & 166,897 & 15,390 & 9.22 \\
\hline WV & 22,985 & 1,122 & 4.88 \\
\hline WI & 100,393 & 11,728 & 11.68 \\
\hline WY & 9,557 & 740 & 7.74 \\
\hline \multicolumn{4}{|l|}{ U.S } \\
\hline Total & $6,293,870$ & 832,925 & 13.23 \\
\hline
\end{tabular}

Source: Authors Calculations using FFIEC HMDA Data 
Table 3: Mortgages Above Cap in Fastest Growing MSA's (Sorted by percentage change in MSA population 1990-2000)

\begin{tabular}{|c|c|c|c|}
\hline MSA & $\begin{array}{c}\text { Total } \\
\text { Originations }\end{array}$ & $\begin{array}{c}\text { Originations } \\
\text { Above Cap }\end{array}$ & $\begin{array}{l}\text { Percent of } \\
\text { Originations } \\
\text { Above Cap }\end{array}$ \\
\hline Las Vegas, NV & 88,324 & 13,515 & 15.30 \\
\hline Naples, FL & 15,630 & 4,298 & 27.50 \\
\hline Yuma, AZ & 3,867 & 241 & 6.23 \\
\hline McAllen--Edinburg--Mission, TX & 6,279 & 308 & 4.91 \\
\hline Austin--San Marcos, TX & 40,770 & 4,273 & 10.48 \\
\hline Fayetteville--Springdale--Rogers, AR & 11,490 & 1,281 & 11.15 \\
\hline Boise City, ID & 19,234 & 1,922 & 9.99 \\
\hline Phoenix--Mesa, AZ & 171,717 & 30,642 & 17.84 \\
\hline Laredo, TX & 2,754 & 158 & 5.74 \\
\hline Provo--Orem, UT & 11,662 & 1,006 & 8.63 \\
\hline Atlanta, GA & 152,932 & 11,850 & 7.75 \\
\hline Raleigh--Durham--Chapel Hill, NC & 27,854 & 4,344 & 15.60 \\
\hline Myrtle Beach, SC & 12,353 & 1,828 & 14.80 \\
\hline Wilmington, $\mathrm{NC}$ & 10,795 & 2,617 & 24.24 \\
\hline Fort Collins--Loveland, $\mathrm{CO}$ & 9,234 & 870 & 9.42 \\
\hline Orlando, FL & 66,656 & 11,866 & 17.80 \\
\hline Reno, NV & 14,178 & 2,013 & 14.20 \\
\hline Ocala, FL & 7,858 & 647 & 8.23 \\
\hline Auburn--Opelika, AL & 2,824 & 279 & 9.88 \\
\hline Fort Myers--Cape Coral, FL & 29,698 & 5,287 & 17.80 \\
\hline West Palm Beach--Boca Raton, FL & 45,514 & 6,676 & 14.67 \\
\hline Bellingham, WA & 4,967 & 819 & 16.49 \\
\hline Denver--Boulder--Greeley, CO & 77,630 & 4,685 & 6.04 \\
\hline Colorado Springs, CO & 18,782 & 1,810 & 9.64 \\
\hline Dallas--Fort Worth, TX & 104,966 & 11,535 & 10.99 \\
\hline Total for fastest growing MSAs & 957,968 & 124,770 & 13.02 \\
\hline
\end{tabular}

Source: Rankings from census.gov, originations from authors calculations 
Table 4: Mortgages Above Cap in Largest MSA's (Sorted by size of MSA)

\begin{tabular}{|c|c|c|c|}
\hline MSA & Total Originations & $\begin{array}{l}\text { Originations } \\
\text { Above Cap }\end{array}$ & $\begin{array}{c}\text { Percent of } \\
\text { Originations } \\
\text { Above Cap }\end{array}$ \\
\hline New York & 124,725 & 30,883 & $24.76 \%$ \\
\hline Los Angeles & 171,708 & 43,447 & $25.30 \%$ \\
\hline Chicago & 192,253 & 23,253 & $12.09 \%$ \\
\hline Philadelphia & 66,516 & 7,900 & $11.88 \%$ \\
\hline Dallas-Fort Worth-Arlington, TX & 104,966 & 11,535 & $10.99 \%$ \\
\hline Miami-Fort Lauderdale-Miami Beach, FL & 71,568 & 5,392 & $7.53 \%$ \\
\hline $\begin{array}{l}\text { Washington-Arlington-Alexandria, DC-VA- } \\
\text { MD }\end{array}$ & 152,663 & 22,825 & $14.95 \%$ \\
\hline Houston-Baytown-Sugar Land, TX & 127,922 & 13,053 & $10.20 \%$ \\
\hline Detroit-Warren-Livonia, MI & 36,357 & 1,502 & $4.13 \%$ \\
\hline Boston-Cambridge-Quincy, MA-NH & 37,786 & 6,869 & $18.18 \%$ \\
\hline Atlanta-Sandy Springs-Marietta, GA & 152,932 & 11,850 & $7.75 \%$ \\
\hline San Francisco-Oakland-Fremont, CA & 29,500 & 19,916 & $67.51 \%$ \\
\hline Riverside-San Bernardino-Ontario, CA & 144,384 & 13,104 & $9.08 \%$ \\
\hline Phoenix-Mesa-Scottsdale, AZ & 171,717 & 30,642 & $17.84 \%$ \\
\hline Seattle-Tacoma-Bellevue, WA & 73,261 & 7,354 & $10.04 \%$ \\
\hline Minneapolis-St. Paul-Bloomington, MN-WI & 82,781 & 8,272 & $9.99 \%$ \\
\hline San Diego-Carlsbad-San Marcos, CA & 79,598 & 26,461 & $33.24 \%$ \\
\hline St. Louis, MO-IL & 62,520 & 3,549 & $5.68 \%$ \\
\hline Baltimore-Towson, MD & 63,480 & 5,904 & $9.30 \%$ \\
\hline Pittsburgh, PA & 32,090 & 3,118 & $9.72 \%$ \\
\hline Tampa-St. Petersburg-Clearwater, FL & 84,978 & 13,486 & $15.87 \%$ \\
\hline Denver-Aurora, CO & 77,630 & 4,685 & $6.04 \%$ \\
\hline Cleveland-Elyria-Mentor, $\mathrm{OH}$ & 39,333 & 2,073 & $5.27 \%$ \\
\hline Cincinnati-Middletown, OH-KY-IN & 45,082 & 4,699 & $10.42 \%$ \\
\hline Portland-Vancouver-Beaverton, OR-WA & 57,822 & 5,534 & $9.57 \%$ \\
\hline Total for largest MSAs & $2,283,572$ & 327,306 & $14.33 \%$ \\
\hline
\end{tabular}

Source: Rankings from census.gov, originations from authors calculations Note: MSAs are sorted by population size. 
Table 5: Mortgages Above Cap in Highest Price MSA's (Sorted by median home price)

\begin{tabular}{|c|c|c|c|}
\hline MSA & Total Originations & $\begin{array}{c}\text { Originations } \\
\text { Above Cap }\end{array}$ & $\begin{array}{l}\text { Percent of } \\
\text { Originations } \\
\text { Above Cap }\end{array}$ \\
\hline San Jose-Sunnyvale-Santa Clara, CA & 39,146 & 20,924 & $53.45 \%$ \\
\hline San Francisco-Oakland-Fremont, CA & 29,500 & 19,916 & $67.51 \%$ \\
\hline Anaheim-Santa Ana, CA (Orange Co.) & 60,303 & 25,618 & $42.48 \%$ \\
\hline San Diego-Carlsbad-San Marcos, CA & 79,598 & 26,461 & $33.24 \%$ \\
\hline Honolulu, HI & 16,978 & 3,207 & $18.89 \%$ \\
\hline Los Angeles-Long Beach-Santa Ana, CA & 171,708 & 43,447 & $25.30 \%$ \\
\hline Bridgeport-Stamford-Norwalk, CT & 19,732 & 5,994 & $30.38 \%$ \\
\hline New York-Wayne-White Plains, NY-NJ & $*$ & $*$ & $*$ \\
\hline NY: Nassau-Suffolk, NY & 46,439 & 8,693 & $18.72 \%$ \\
\hline Boston-Cambridge-Quincy, MA-NH & 37,786 & 6,869 & $18.18 \%$ \\
\hline New York-Northern New Jersey-Long Island, NY-NJ-PA & $*$ & $*$ & * \\
\hline Barnstable Town, MA & 6,599 & 1,247 & $18.90 \%$ \\
\hline NY: Newark-Union, NJ-PA & 38,876 & 5,687 & $14.63 \%$ \\
\hline Washington-Arlington-Alexandria, DC-VA-MD-WV & 152,663 & 22,825 & $14.95 \%$ \\
\hline NY: Edison, NJ & 47,891 & 5,495 & $11.47 \%$ \\
\hline Boulder, $\mathrm{CO}$ & 7,556 & 896 & $11.86 \%$ \\
\hline Sacramento--Arden-Arcade--Roseville, CA & 71,611 & 7,820 & $10.92 \%$ \\
\hline Riverside-San Bernardino-Ontario, CA & 144,384 & 13,104 & $9.08 \%$ \\
\hline Miami-Fort Lauderdale-Miami Beach, FL & 71,568 & 5,392 & $7.53 \%$ \\
\hline Seattle-Tacoma-Bellevue, WA & 73,261 & 7,354 & $10.04 \%$ \\
\hline Reno-Sparks, NV & 14,178 & 2,013 & $14.20 \%$ \\
\hline Providence-New Bedford-Fall River, RI-MA & 29,810 & 1,739 & $5.83 \%$ \\
\hline Worcester, MA & 16,902 & 890 & $5.27 \%$ \\
\hline Las Vegas-Paradise, NV & 88,324 & 13,515 & $15.30 \%$ \\
\hline Sarasota-Bradenton-Venice, FL & 27,048 & 5,599 & $20.70 \%$ \\
\hline
\end{tabular}


Table 6: Mortgages Above Cap for MSAs with the Fastest Price Increases (Sorted by percentage change in median sales price, 2003-2004)

\begin{tabular}{|c|c|c|c|}
\hline MSA & $\begin{array}{c}\text { Total } \\
\text { Originations }\end{array}$ & $\begin{array}{c}\text { Originations } \\
\text { Above Cap }\end{array}$ & $\begin{array}{l}\text { Percent of } \\
\text { Originations } \\
\text { Above Cap }\end{array}$ \\
\hline Las Vegas-Paradise, NV & 88,324 & 13,515 & $15.30 \%$ \\
\hline Reno-Sparks, NV & 14,178 & 2,013 & $14.20 \%$ \\
\hline Riverside-San Bernardino-Ontario, CA & 144,384 & 13,104 & $9.08 \%$ \\
\hline Sarasota-Bradenton-Venice, FL & 27,048 & 5,599 & $20.70 \%$ \\
\hline San Diego-Carlsbad-San Marcos, CA & 79,598 & 26,461 & $33.24 \%$ \\
\hline Anaheim-Santa Ana, CA (Orange Co.) & 60,303 & 25,618 & $42.48 \%$ \\
\hline Sacramento--Arden-Arcade--Roseville, CA & 71,611 & 7,820 & $10.92 \%$ \\
\hline Los Angeles-Long Beach-Santa Ana, CA & 171,708 & 43,447 & $25.30 \%$ \\
\hline Palm Bay-Melbourne-Titusville, FL & 27,048 & 5,599 & $20.70 \%$ \\
\hline Miami-Fort Lauderdale-Miami Beach, FL & 71,568 & 5,392 & $7.53 \%$ \\
\hline Cape Coral-Fort Myers, FL & 29,698 & 5,287 & $17.80 \%$ \\
\hline Washington-Arlington-Alexandria, DC-VA-MD-WV & 152,663 & 22,825 & $14.95 \%$ \\
\hline Honolulu, HI & 16,978 & 3,207 & $18.89 \%$ \\
\hline Baltimore-Towson, MD & 63,480 & 5,904 & $9.30 \%$ \\
\hline Seattle-Tacoma-Bellevue, WA & 73,261 & 7,354 & $10.04 \%$ \\
\hline Deltona-Daytona Beach-Ormond Beach, FL & 14,724 & 2,053 & $13.94 \%$ \\
\hline Atlantic City, NJ & 7,461 & 726 & $9.73 \%$ \\
\hline Pittsfield, MA & 2,200 & 443 & $20.14 \%$ \\
\hline San Jose-Sunnyvale-Santa Clara, CA & 39,146 & 20,924 & $53.45 \%$ \\
\hline Virginia Beach-Norfolk-Newport News, VA-NC & 41,029 & 1,687 & $4.11 \%$ \\
\hline Kingston, NY & 2,738 & 791 & $28.89 \%$ \\
\hline Hagerstown-Martinsburg, MD-WV & 6,754 & 188 & $2.78 \%$ \\
\hline Dover, DE & 3,639 & 357 & $9.81 \%$ \\
\hline Orlando, FL & 66,656 & 11,866 & $17.80 \%$ \\
\hline Portland-South Portland-Biddeford, ME & 11,196 & 1,228 & $10.97 \%$ \\
\hline
\end{tabular}

Source: Rankings from National Association of Realtors, originations from authors calculations Note: MSAs are sorted by the percentage increase in median sales price 2003-2004. 
Table 7: Mortgage Amounts in Excess of Cap (2004 dollars)

\begin{tabular}{|c|c|c|}
\hline State & Average Mortgage Amount Over Cap & Standard Deviation \\
\hline AK & 85,184 & 257,880 \\
\hline $\mathrm{AL}$ & 129,739 & 524,561 \\
\hline AR & 127,710 & 443,818 \\
\hline AZ & 131,114 & 272,090 \\
\hline $\mathrm{CA}$ & 210,049 & 493,788 \\
\hline $\mathrm{CO}$ & 189,532 & 459,896 \\
\hline $\mathrm{CT}$ & 282,031 & 541,314 \\
\hline $\mathrm{DE}$ & 134,826 & 496,412 \\
\hline $\mathrm{DC}$ & 235,351 & 448,281 \\
\hline FL & 179,790 & 541,485 \\
\hline GA & 148,571 & 593,226 \\
\hline $\mathrm{HI}$ & 179,901 & 303,350 \\
\hline ID & 115,095 & 227,238 \\
\hline IL & 168,627 & 440,930 \\
\hline IN & 123,651 & 447,553 \\
\hline IA & 98,756 & 298,355 \\
\hline KS & 122,207 & 339,408 \\
\hline KY & 154,817 & 463,841 \\
\hline LA & 112,894 & 374,230 \\
\hline $\mathrm{ME}$ & 126,941 & 233,526 \\
\hline $\mathrm{MD}$ & 159,846 & 362,176 \\
\hline MA & 187,540 & 461,736 \\
\hline MI & 126,235 & 356,200 \\
\hline $\mathrm{MN}$ & 133,708 & 408,274 \\
\hline MS & 128,243 & 506,661 \\
\hline $\mathrm{MO}$ & 153,369 & 565,837 \\
\hline MT & 128,849 & 475,060 \\
\hline $\mathrm{NE}$ & 97,436 & 312,234 \\
\hline NV & 148,799 & 518,137 \\
\hline NH & 122,832 & 223,072 \\
\hline NJ & 183,429 & 358,846 \\
\hline NM & 116,334 & 411,853 \\
\hline NY & 221,167 & 526,330 \\
\hline $\mathrm{NC}$ & 145,556 & 515,653 \\
\hline ND & 87,840 & 193,922 \\
\hline $\mathrm{OH}$ & 128,959 & 480,539 \\
\hline $\mathrm{OK}$ & 137,127 & 619,616 \\
\hline OR & 124,781 & 313,965 \\
\hline PA & 123,305 & 411,758 \\
\hline RI & 215,987 & 645,489 \\
\hline $\mathrm{SC}$ & 153,777 & 380,260 \\
\hline SD & 100,443 & 279,088 \\
\hline $\mathrm{TN}$ & 122,828 & 377,442 \\
\hline $\mathrm{TX}$ & 154,672 & 613,453 \\
\hline UT & 132,921 & 430,043 \\
\hline VT & 125,722 & 179,462 \\
\hline VA & 134,689 & 402,392 \\
\hline WA & 152,202 & 370,975 \\
\hline WV & 132,996 & 404,458 \\
\hline WI & 149,633 & 501,770 \\
\hline WY & 116,147 & 281,459 \\
\hline
\end{tabular}

Source: Authors calculations 
Table 8: Income and Race Summary for All Mortgage Originations (Income in thousands of 2004 dollars)

\begin{tabular}{|c|c|c|c|c|c|c|}
\hline & Average Income & Standard Deviation & Median Income & $\%$ Asian & $\%$ Black & $\%$ White \\
\hline $\mathrm{AK}$ & 82 & 66 & 68 & 4.61 & 2.63 & 82.58 \\
\hline $\mathrm{AL}$ & 72 & 93 & 53 & 1.17 & 13.92 & 77.43 \\
\hline $\mathrm{AR}$ & 71 & 119 & 51 & 1.32 & 7.24 & 81.68 \\
\hline $\mathrm{AZ}$ & 91 & 124 & 66 & 3.15 & 2.26 & 77.09 \\
\hline CA & 126 & 163 & 96 & 12.19 & 4.03 & 59.82 \\
\hline $\mathrm{CO}$ & 92 & 137 & 67 & 2.20 & 2.82 & 82.99 \\
\hline CT & 109 & 176 & 76 & 3.21 & 6.79 & 75.79 \\
\hline $\mathrm{DE}$ & 98 & 143 & 70 & 2.81 & 11.25 & 74.20 \\
\hline DC & 133 & 169 & 97 & 3.97 & 24.41 & 51.31 \\
\hline FL & 104 & 177 & 70 & 2.38 & 6.79 & 76.65 \\
\hline GA & 81 & 112 & 60 & 3.45 & 22.71 & 61.87 \\
\hline HI & 128 & 201 & 90 & 30.28 & 1.46 & 49.77 \\
\hline ID & 76 & 115 & 54 & 1.26 & 0.44 & 89.60 \\
\hline IL & 87 & 115 & 67 & 5.21 & 9.41 & 75.51 \\
\hline IN & 67 & 73 & 52 & 1.44 & 5.91 & 85.93 \\
\hline IA & 66 & 108 & 52 & 1.52 & 1.37 & 88.98 \\
\hline KS & 73 & 100 & 57 & 2.48 & 3.12 & 83.04 \\
\hline KY & 69 & 86 & 52 & 1.17 & 5.17 & 85.15 \\
\hline LA & 73 & 116 & 54 & 1.92 & 17.08 & 71.77 \\
\hline ME & 83 & 94 & 60 & 0.81 & 0.50 & 89.73 \\
\hline MD & 99 & 108 & 78 & 6.19 & 20.83 & 59.77 \\
\hline MA & 109 & 147 & 83 & 4.82 & 4.97 & 77.35 \\
\hline MI & 76 & 98 & 59 & 2.32 & 10.11 & 80.11 \\
\hline MN & 81 & 101 & 62 & 4.09 & 3.14 & 84.54 \\
\hline MS & 70 & 98 & 51 & 1.12 & 18.81 & 71.19 \\
\hline MO & 70 & 90 & 54 & 1.65 & 7.48 & 80.28 \\
\hline MT & 81 & 141 & 55 & 0.63 & 0.24 & 92.99 \\
\hline $\mathrm{NE}$ & 69 & 66 & 55 & 1.86 & 2.42 & 88.65 \\
\hline $\mathrm{NV}$ & 108 & 151 & 78 & 11.00 & 3.75 & 69.87 \\
\hline $\mathrm{NH}$ & 94 & 104 & 74 & 2.12 & 0.76 & 86.68 \\
\hline NJ & 118 & 151 & 89 & 8.00 & 7.41 & 69.21 \\
\hline NM & 79 & 89 & 60 & 1.85 & 1.51 & 80.32 \\
\hline NY & 119 & 213 & 83 & 7.02 & 8.57 & 69.89 \\
\hline $\mathrm{NC}$ & 83 & 102 & 60 & 2.17 & 11.79 & 74.54 \\
\hline ND & 65 & 59 & 53 & 0.81 & 0.39 & 93.22 \\
\hline $\mathrm{OH}$ & 71 & 78 & 56 & 1.80 & 7.86 & 82.85 \\
\hline OK & 69 & 96 & 52 & 2.00 & 4.80 & 80.95 \\
\hline OR & 85 & 131 & 63 & 3.79 & 1.03 & 85.37 \\
\hline PA & 80 & 93 & 62 & 3.76 & 4.89 & 80.38 \\
\hline RI & 95 & 114 & 72 & 2.11 & 4.59 & 77.24 \\
\hline $\mathrm{SC}$ & 87 & 118 & 60 & 1.33 & 11.05 & 76.92 \\
\hline SD & 67 & 78 & 51 & 0.63 & 0.46 & 91.91 \\
\hline $\mathrm{TN}$ & 70 & 82 & 52 & 1.48 & 12.51 & 76.60 \\
\hline $\mathrm{TX}$ & 87 & 123 & 65 & 4.35 & 8.55 & 71.95 \\
\hline UT & 75 & 131 & 54 & 1.52 & 0.54 & 86.85 \\
\hline VT & 108 & 173 & 68 & 1.20 & 0.46 & 86.58 \\
\hline VA & 96 & 98 & 77 & 7.95 & 9.70 & 68.46 \\
\hline WA & 88 & 138 & 68 & 6.95 & 2.28 & 77.90 \\
\hline WV & 70 & 71 & 54 & 1.01 & 1.92 & 89.02 \\
\hline WI & 78 & 87 & 60 & 2.04 & 3.44 & 87.06 \\
\hline WY & 71 & 92 & 54 & 0.66 & 0.52 & 92.43 \\
\hline
\end{tabular}

Source: Authors calculations 
Table 9: Income and Race Summary for Mortgage Originations Above Proposed Caps (Income in thousands of 2004 dollars)

\begin{tabular}{|c|c|c|c|c|c|c|}
\hline & Average Income & Standard Deviation & Median Income & $\%$ Asian & $\%$ Black & $\%$ White \\
\hline $\mathrm{AK}$ & 148 & 129 & 118 & 3.91 & 2.28 & 81.43 \\
\hline $\mathrm{AL}$ & 162 & 193 & 118 & 1.76 & 6.75 & 82.60 \\
\hline AR & 157 & 177 & 117 & 1.94 & 4.02 & 81.70 \\
\hline $\mathrm{AZ}$ & 157 & 226 & 114 & 3.41 & 1.85 & 78.87 \\
\hline $\mathrm{CA}$ & 200 & 257 & 147 & 16.34 & 2.53 & 60.83 \\
\hline $\mathrm{CO}$ & 225 & 345 & 149 & 1.98 & 1.16 & 84.11 \\
\hline $\mathrm{CT}$ & 275 & 408 & 178 & 3.39 & 1.72 & 79.82 \\
\hline $\mathrm{DE}$ & 206 & 294 & 144 & 2.70 & 5.82 & 77.72 \\
\hline $\mathrm{DC}$ & 239 & 300 & 170 & 3.72 & 8.19 & 65.37 \\
\hline FL & 229 & 359 & 147 & 2.48 & 3.20 & 80.33 \\
\hline GA & 182 & 260 & 136 & 3.81 & 10.81 & 72.24 \\
\hline $\mathrm{HI}$ & 212 & 330 & 140 & 22.41 & 1.19 & 59.84 \\
\hline ID & 174 & 254 & 116 & 1.15 & 0.20 & 87.91 \\
\hline IL & 195 & 244 & 144 & 7.94 & 3.80 & 76.23 \\
\hline IN & 155 & 190 & 118 & 3.26 & 3.42 & 84.33 \\
\hline IA & 139 & 115 & 111 & 2.26 & 1.41 & 86.81 \\
\hline $\mathrm{KS}$ & 176 & 239 & 131 & 3.19 & 2.48 & 81.04 \\
\hline KY & 166 & 216 & 119 & 2.51 & 3.00 & 83.23 \\
\hline LA & 166 & 261 & 117 & 2.37 & 7.73 & 77.33 \\
\hline $\mathrm{ME}$ & 196 & 196 & 138 & 0.81 & 0.23 & 85.37 \\
\hline MD & 192 & 221 & 150 & 8.59 & 11.21 & 65.64 \\
\hline MA & 222 & 292 & 156 & 5.23 & 3.46 & 76.30 \\
\hline MI & 177 & 243 & 131 & 4.73 & 4.25 & 81.79 \\
\hline $\mathrm{MN}$ & 172 & 232 & 130 & 3.56 & 1.82 & 84.55 \\
\hline MS & 165 & 217 & 114 & 1.85 & 11.26 & 76.38 \\
\hline MO & 180 & 225 & 136 & 3.00 & 3.13 & 80.01 \\
\hline MT & 196 & 361 & 115 & 0.57 & 0.23 & 90.61 \\
\hline NE & 148 & 144 & 115 & 2.26 & 1.82 & 87.06 \\
\hline NV & 193 & 304 & 134 & 12.47 & 3.11 & 71.09 \\
\hline NH & 187 & 225 & 132 & 1.94 & 0.48 & 85.17 \\
\hline NJ & 247 & 291 & 179 & 9.90 & 3.38 & 69.94 \\
\hline NM & 157 & 165 & 119 & 2.52 & 1.39 & 81.00 \\
\hline NY & 263 & 425 & 160 & 9.84 & 6.31 & 65.10 \\
\hline $\mathrm{NC}$ & 170 & 190 & 125 & 2.63 & 4.46 & 81.36 \\
\hline ND & 153 & 109 & 117 & 1.69 & 0.00 & 88.19 \\
\hline $\mathrm{OH}$ & 161 & 164 & 125 & 3.59 & 4.37 & 82.19 \\
\hline OK & 171 & 208 & 123 & 2.58 & 3.59 & 81.30 \\
\hline OR & 162 & 207 & 120 & 3.87 & 0.84 & 83.75 \\
\hline PA & 168 & 188 & 130 & 4.54 & 3.07 & 80.03 \\
\hline RI & 275 & 342 & 184 & 2.36 & 1.22 & 80.49 \\
\hline $\mathrm{SC}$ & 199 & 241 & 135 & 1.43 & 3.74 & 83.65 \\
\hline SD & 154 & 151 & 110 & 1.07 & 0.47 & 89.34 \\
\hline $\mathrm{TN}$ & 164 & 163 & 125 & 2.40 & 7.62 & 79.11 \\
\hline $\mathrm{TX}$ & 196 & 274 & 143 & 5.12 & 5.92 & 74.09 \\
\hline UT & 185 & 364 & 120 & 1.52 & 0.43 & 85.73 \\
\hline VT & 267 & 372 & 160 & 1.23 & 0.51 & 82.75 \\
\hline VA & 172 & 156 & 140 & 10.66 & 5.21 & 68.24 \\
\hline WA & 178 & 256 & 133 & 6.64 & 1.31 & 76.19 \\
\hline WV & 170 & 141 & 128 & 3.21 & 1.34 & 81.71 \\
\hline WI & 159 & 167 & 117 & 2.64 & 1.53 & 84.11 \\
\hline WY & 174 & 245 & 105 & 1.08 & 0.54 & 89.59 \\
\hline
\end{tabular}

Source: Authors calculations 


\section{References}

Anderson, John E. and Atrayee Ghosh Roy, 2001. "Eliminating Housing Tax Preferences: A Distributional Analysis," Journal of Housing Economics, Volume 10, Issue 1, pp. 41-58.

Brady, Peter, Julie-Anne Cronin, and Scott Houser, 2003. "Regional Differences in the Utilization of the Mortgage Interest Deduction," Public Finance Review, Volume 31, Number 4 (July) pp. 327-366.

Capozza, Dennis R., Richard K. Green, and Patric H. Hendershott, 1996. “Taxes, Mortgage Borrowing, and Residential Land Prices," pp. 171-210 in William Gale and Henry Aaron, editors, The Economics Effects of Fundamental Tax Reform, Washington, DC: Brookings Institution.

Executive Office of the President, Office of Management and Budget, 2006. Analytical Perspectives, Budget of the United States Government Fiscal Year 2007, U.S. Government Printing Office, Washington, DC.

Follain, James R. and David C. Ling, 1991. "The Federal Tax Subsidy to Housing and the Reduced Value of the Mortgage Interest Deduction," National Tax Journal, Volume 44, Number 2 (June), pp. 147-168.

Follain, James R. and Lisa Sturman Melamed, 1998. "The False Messiah of Tax Policy: What Elimination of the Home Mortgage Interest Deduction Promises and a Careful Look at What it Delivers," Journal of Housing Research, Volume 9, Issue 2, pp. 179-199.

Glaeser, Edward L. and Jesse M. Shapiro, 2002. "The Benefits of the Home Mortgage Interest Deduction," NBER working paper 9284.

Green, Richard K. and Kerry D. Vandell, 1999. "Giving Households Credit: How Changes in the U.S. Tax Code Could Promote Homeownership," Regional Science and Urban Economics, Volume 29, Number 4 (July) pp. 419-444.

Himmelberg, Charles, Christopher Mayer, and Todd Sinai, 2005. “Assessing High House Prices: Bubbles, Fundamentals, and Misperceptions," Journal of Economic Perspectives, Volume 19, Number 4 (Fall) pp. 67-92.

Hotz-Eakin, Douglas, 1996. Comment on, "Taxes, Mortgage Borrowing, and Residential Land Prices," pp. 198-210 in William Gale and Henry Aaron, editors, The Economics Effects of Fundamental Tax Reform, Washington, DC: Brookings Institution.

Mills, Edwin S., 1989. "Social Returns to Housing and Other Fixed Capital," Journal of the American Real Estate and Urban Economics Association, Volume 17, Number 2 (Summer) pp. 197-211.

Poterba, James M., 1992. "Taxation and Housing: Old Questions, New Answers," American Economic Review, Volume 82, Number 2 (May), pp. 237-242. 
Poterba, James M., 1984. "Tax Subsidies to Owner-Occupied Housing: An Asset Market Approach," Quarterly Journal of Economics, Volume 99, Number 4 (November) pp. 729-752.

President's Advisory Panel on Federal Tax Reform, 2005. Simple, Fair, and Pro-Growth: Proposals to Fix America's Tax System, U.S. Government Printing Office, Washington, DC.

Rosen, Harvey S., 1985. "Housing Subsidies: Effects on Housing Decisions, Efficiency, and Equity," in M. Feldstein and A. Auerbach, editors, Handbook of Public Economics, Volume 1, Amsterdam: North-Holland, pp. 375-420.

Sinai, Todd and Nicholas S. Souleles, 2005. "Owner-Occupied Housing as a Hedge Against Rent Risk," Quarterly Journal of Economics, Volume 120, Number 2 (May) pp. 763-789. 